\title{
A FIZIKAI INTÉZET RA-BE NEUTRONFORRÁSÁNAK FELHASZNÁLÁSA ÉS ELTEMETÉSE
}

\author{
Paripás Béla \\ egyetemi tanár, Miskolci Egyetem, Fizikai és Elektrotechnikai Intézet \\ 3515 Miskolc, Miskolc-Egyetemváros, e-mail: fizpari@uni-miskolc.hu

\section{Béres Miklós} \\ mérnöktanár, Miskolci Egyetem, Fizikai és Elektrotechnikai Intézet \\ 3515 Miskolc, Miskolc-Egyetemváros, e-mail: mechbere@uni-miskolc.hu
}

\section{Tóth Leonóra}

környezetmérnök, Inis Kft.

4025 Debrecen, Arany János u. 54., e-mail: titkarsag@inis.hu

\section{Csepura György}

cimzetes egyetemi docens, Inis $\mathrm{Kft}$.

4025 Debrecen, Arany János u. 54., e-mail: titkarsag@inis.hu

\begin{abstract}
Absztrakt
A 44 éven át oktatási célra használt laboratóriumi rádium-226-berillium neutronforrás felhasználási ideje lejárt, eltemetése szükségessé vált. A forrás szétszerelése, temetésre elökészitése egyedülálló, szakmailag komoly feladatot jelentett. A cikkben beszámolunk a feladat elöírások szerinti végrehajtásáról. A mérési eredmények alapján a radioaktív hulladéktemetönek egy sértetlen, teljesen zárt izotópot adtunk át.
\end{abstract}

Kulcsszavak: Ra-226, Ra-Be neutronforrás, izotóp temetés

\begin{abstract}
The period of service of our laboratory Radium-226 - Beryllium neutron source, used in our education for 44 years, is expired so its disposal became necessary. The disassembling of the source, its preparation for disposal was a unique, professional challenge. In this paper we show the performance of this work, with regard to the referring regulations. On the basis of our measurements we delivered an uninjured closed isotope to the radioactive waste disposal facility.
\end{abstract}

Keywords: Ra-226, Ra-Be neutron source, disposal of radioactive material

\section{Bevezetés}

A Miskolci Egyetem Fizikai Intézete (korábban Fizikai Tanszéke) 44 évvel ezelőtt hozzájutott egy Leybold gyártmányú rádium-226-berilium neutronforráshoz. Ez a sugárforrás laboratóriumi körülmények között használható, alkalmas neutronos mérőmüszerek tesztelésére, oktatási célú neutronaktivációs vizsgálatokra, igen kis aktivitású, igen kis felezési idejü radioizotópok előállítására. A neutronforrást mindig a hatályos (egyre szigorodó) jogszabályok alapján üzemeltettük, ill. tároltuk. A legutóbbi jogszabály változások [1] miatt a forrás felhasználási ideje már nem hosszabbítható meg. 
Lejárt felhasználási idejü sugárforrás felhasználása pedig tilos, ezért annak eltemetéséről intézkednünk kellett. Ennek lebonyolítására a témában megfelelő gyakorlattal és engedéllyel rendelkező Inis Kft.-t [2] kértük fel. A temetésre való előkészítést nehezítette az, hogy semmilyen leírás nem állt rendelkezésre (kivéve a forrás mübizonylatát). Sugárvédelmi szempontból külön kihívásokat jelentett a sugárforrás magas gamma sugárzása és a müködés közben keletkező radon is. Szerencsére minden aggodalom fölöslegesnek bizonyult, a 44 év alatt a forrás sértetlen maradt, a mérési eredmények alapján a radioaktív hulladéktemetőnek egy teljesen zárt izotópot tudtunk átadni.

\section{A sugárforrás fizikai jellemzői}

\subsection{Külső megjelenés}

A Fizikai Intézet neutron aktivációs berendezésében a neutronokat egy rádium-226-berillium (a továbbiakban Ra-226-Be) zárt sugárforrást szolgáltatja. A zártság azt jelenti, hogy a radioaktív sugárforrást olyan anyagba ágyazzák be, azaz olyan tokozásba teszik, amely rendeltetésszerü használat során megakadályozza a forrás környezetbe való kijutását. A neutronforrásban a berillium atommagját eltaláló alfa részecskék által kiváltott magreakció termeli a neutronokat.

A sugárforrás egy $49 \mathrm{~cm}$ átméröjü, 46-47 $\mathrm{cm}$ magas hengeres edényben (egy kb. 85 literes fazékban) van elhelyezve, ami paraffinnal van kiöntve. Ezt a fazekat egy még nagyobb $(\mathrm{kb} .90 \mathrm{~cm}$ átmérőjü és $1 \mathrm{~m}$ magas) hengeres tartály foglalja magába excentrikus módon úgy, hogy a fazék belülről hozzáér a tartály falához. Ez a tartály a mobilizálhatóságot (kerekei, fogantyuui, zárja van) és a távolság védelmet szolgálja (1. ábra).
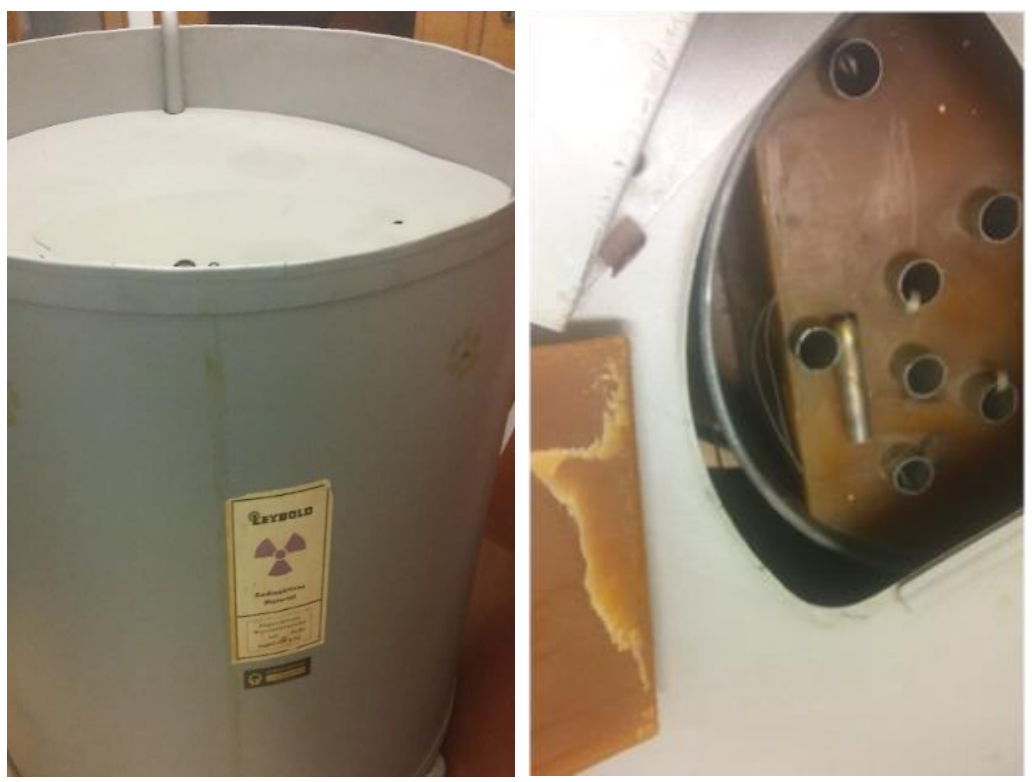

1. ábra. A sugárforrást tartalmazó tartály oldalról (balra) és felülröl nyitott állapotban (jobbra)

Ahhoz hogy az eszköz alkalmas legyen neutron aktivációs analízisek [3] laboratóriumi vizsgálatára hét darab besugárzási csatornát helyeztek el benne. A sugárforrás a neutronsugárzás mellett erős gammasugárzó, ezért az izotópot a gyártás során ólomtégelybe helyezték. Ennek pontos pozíciójáról az eszköz szétszedése előtt nem volt információnk, az ábrán már ezt is feltüntettük (2. ábra). 


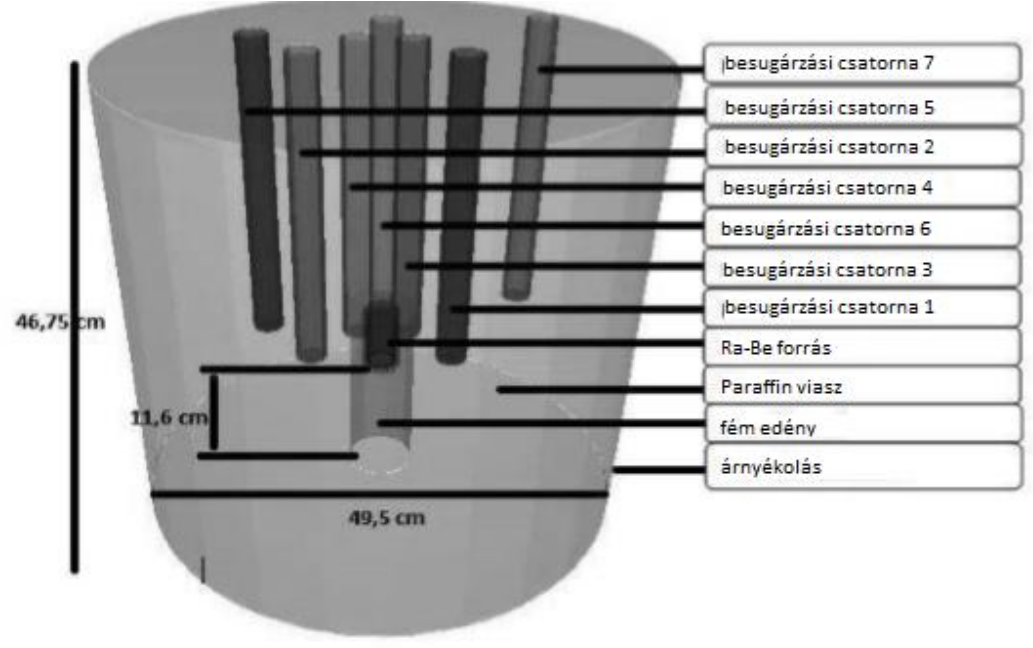

2. ábra. A sugárforrást tartalmazó fazék keresztmetszeti rajza

\subsection{Radioaktivitás}

A sugárforrást 1975-ben gyártották, ekkor a Ra-226 radioaktivitása (a továbbiakban aktivitása) 111 $\mathrm{MBq}$ volt $(1 \mathrm{~Bq}=1$ becquerel $=1$ bomlás $/ \mathrm{sec})$. A forrás ,életének” 44 éve alatt az aktivitás figyelembe véve az 1620 éves felezési időt - kb. 1,9\%-ot csökkent, tehát a temetéskor kb. $109 \mathrm{MBq}$ volt. A rádium radonná alakul, ami 3,82 nap felezési idővel tovább bomlik polóniummá, a polónium ólommá és így tovább, végül az egész bomlási sor jelen lesz egy zárt sugárforrásban (3. ábra).

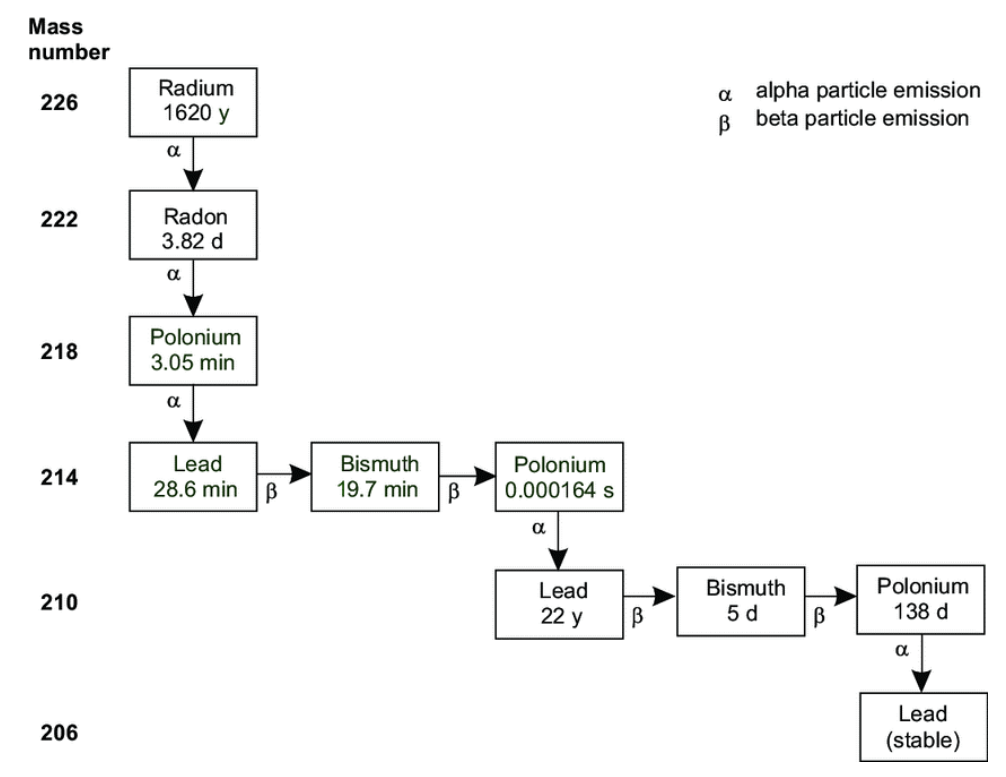

3. ábra. A Ra-226 bomlási sora [4]

Az egyensúly beállásához a polónium izotópokkal bezárólag néhány hétnyi idő szükséges (ez valószínűleg még a gyárában bekövetkezett). A nálunk lévő sugárforrásban tehát (a gyártást követő 
évben, másodpercenként átlagosan) 111 millió alfa bomlást „szenvedett el” mind a négy alfa sugárzó izotóp (Ra-226, Rn-222, Po-218, Po-214), azaz másodpercenként 444 millió $\left(4,44 \times 10^{8}\right)$ He atom keletkezett. Az ötödik alfa sugárzó izotóp (Po-210) azonban - az ólom-210 izotóp 22 éves felezési ideje miatt - még a forrásunk 44 éves léte végére sem kerül radioaktív egyensúlyba, a temetéskor az egyensúlyi mennyiség $75 \%$-át érhette el. Másképpen fogalmazva a Po-210 aktivitásának növekedése (nulláról kb. $80 \mathrm{MBq}$-ig) miatt a sugárforrás összes alfa aktivitása a temetéskor $516 \mathrm{MBq}$ lehetett, azaz kb. 16\%-kal magasabb, mint a gyártást követö évben.

A bomlástermékek közül a Rn-222 nemesgáz, amely a radioaktív forrásból kijuthat (ill. kijuthatna, ha az nyitottá válna). Ha például az egyensúlyi $111 \mathrm{MBq}$ aktivitású radon 10\%-a kijutna a mintából (a $10 \%$ egy realisztikus emanációs tényező), akkor az a $10 \mathrm{~m}^{3}$-es izotóptároló helyiségben $1,1 \mathrm{MBq} / \mathrm{m}^{3}$, a $100 \mathrm{~m}^{3}$-es laboratóriumban pedig $110 \mathrm{kBq} / \mathrm{m}^{3}$ radon aktivitáskoncentrációt eredményezne. Ez még az uránbányákra régebben megengedett munkaszintet $\left(1 \mathrm{WL}\right.$ (working level) $=3,7 \mathrm{kBq} / \mathrm{m}^{3}$ egyensúlyi radon aktivitáskoncentráció [5]) is több nagyságrenddel meghaladja (hogy a ma engedélyezett 300 $\mathrm{Bq} / \mathrm{m}^{3}$-röl ne is beszéljünk). A sugárforrás nyitottá válása (azaz a zártság megszünése) tehát igen komoly probléma lenne. A zártság meglétét a vonatkozó rendelet szerint 3 évente ellenőriztük és mindig rendben találtuk. Az egyensúlyi $111 \mathrm{MBq}$-nyi radon egyébként mindösszesen $5,29 \times 10^{13} \mathrm{db}$ radon atomot jelent, amely atmoszférikus nyomáson csak $0,002 \mathrm{~mm}^{3}$ térfogatot foglal el (ami egy mákszem térfogatánál is kisebb).

Egészen más a helyzet alfa bomlások során keletkező héliummal, mert zárt sugárforrásban ez folyamatosan szaporodik. Ahogy korábban is utaltunk rá, a 44 év átlagában másodpercenként 480 millió He atom keletkezik. Ez évente $\left(1\right.$ év $\left.=3,15 \times 10^{7} \mathrm{~s}\right) 1,514 \times 10^{16} \mathrm{He}$ atom, a 44 év alatt pedig $6,66 \times 10^{17} \mathrm{He}$ atom. Ez kb. $25 \mathrm{~mm}^{3}$ térfogatot foglal el $\left(20^{\circ} \mathrm{C}, 1 \mathrm{~atm}\right.$.). Nem tudhatjuk pontosan, hogy az $1 \mathrm{~cm}^{3}$-nyinek becsült sugárforrásba pontosan mekkora térfogatú levegőt zártak be a gyártáskor, de az nagyon valószínü, hogy a keletkezett hélium nem növeli meg veszélyes mértékben a sugárforrás belsejében a nyomást. Még azt sem zárhatjuk ki, hogy a keletkezett kicsi ( $r \sim 30 \mathrm{pm})$ hélium atomok egy része mikroméretü hibákon keresztül kijut a zárt sugárforrásból, miközben a nagyobb $(\mathrm{r} \sim 120 \mathrm{pm})$ radon atomok [6] nem (ez utóbbit biztosan tudjuk a zártság vizsgálatok eredményéből).

\subsection{A neutronok keltése}

A neutronokat a berillium atommagját elérő alfa részecskék keltik a

$$
{ }_{4}^{9} \mathrm{Be}+{ }_{2}^{4} \mathrm{He} \rightarrow{ }_{6}^{12} \mathrm{C}+n
$$

reakcióban. A sugárforrásban a rádium és berillium por össze van keverve és préselve, hogy az alfa részecskéknek minél nagyobb esélye legyen arra, hogy a berillium atommagját eltalálják [7]. Ez az esély azonban nagyon kicsi, merthogy az atommag is nagyon kicsi az atom méretéhez képest és az az alfa részecskék pedig igen kis távolságon belül (néhány $\mu \mathrm{m}$ ) lefékeződnek az elektronokkal való kölcsönhatás miatt. Ráadásul nem is kell teljesen lefékeződniük, a kis sebességü alfa részecskék már nem tudnak áthatolni a berillium atommag Coulomb-gátján. Összességében nagyjából csak minden tízezredik alfa részecske találhat célba és kelthet neutront. Irodalmi adatok alapján [8] a neutronhozamnak valahol $4-5 \cdot 10^{4}$ neutron/s körül kellene lennie, a mübizonylaton az MTA Izotóp Intézete a $3 \cdot 10^{4}$ neutron/s értéket szerepelteti. (Megjegyezzük, hogy más ugyanekkora radioaktivitású neutronforrások (Po-Be, $\mathrm{Pu}-\mathrm{Be}, \mathrm{Am}-\mathrm{Be})$ neutron hozama még ennél is kisebb, mert nálunk legalább „besegítenek” a leányelemek is.) 
A korábbi számolást követve: ha másodpercenként 40 ezer neutron keletkezik, akkor ez évente (1 év $\left.=3,15 \times 10^{7} \mathrm{~s}\right) 1,26 \times 10^{12}$ neutron, a 44 év alatt pedig $5,54 \times 10^{13}$ neutron. Minden neutron keltéséhez egy berillium atom szénatommá alakulása szükséges. A $3 \mathrm{mCi}$ aktivitású rádium tömege (a Ci definíciója alapján) éppen $3 \mathrm{mg}$. Feltételezhetjük, hogy ezt legalább ekkora tömegü berilliumhoz keverték. A $3 \mathrm{mg}$ berillium 1/3000 mol, ami $2 \times 10^{20}$ atomot tartalmaz, a neutron keltés ennek egy milliomod részét sem fogyasztotta el a 44 év alatt. A neutron hozam tehát minden bizonnyal követi az alfa aktivitást, azaz a sugárforrás temetéskor az is kb. 16\%-kal magasabb lehetett, mint a gyártást követő évben.

Mivel a neutront keltő alfa részecskék energiája igen sokféle lehet és a szén atommag is többféle gerjesztett állapotban keletkezhet, a keletkezett (primer) neutronok energia spektruma igen bonyolult (4. ábra). Az ábrán látható, hogy 0 és $12 \mathrm{MeV}$ között minden neutron energia előfordul, az átlag valahol $5 \mathrm{MeV}$ körül lehet.

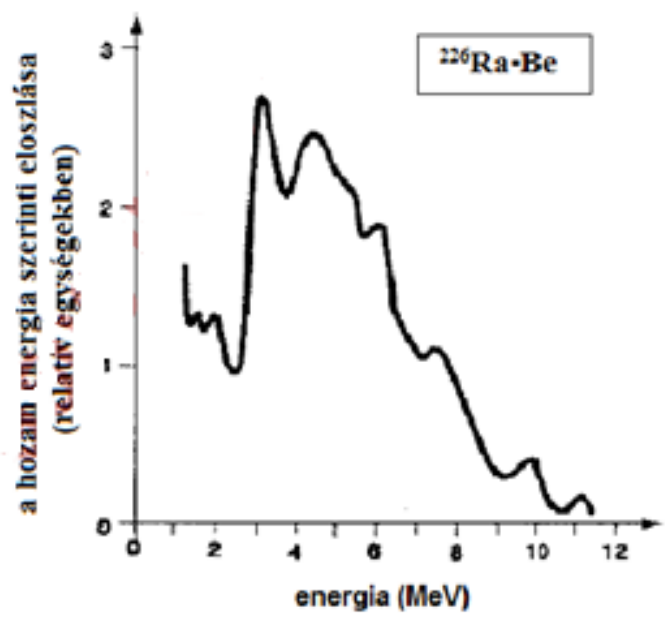

\section{4. ábra. A Ra-Be neutronforrásban keletkezö neutronok energia spektruma [9]}

A neutron semlegességének következménye, hogy könnyen áthatol a legtöbb anyagon, mivel elektromágneses kölcsönhatást nem létesít az anyaggal. A neutronsugárzás árnyékolására nem is alkalmasak a gamma- és röntgensugarakat jól abszorbeálni tudó nagy rendszámú anyagok (pl. ólomlemez). A hatékony árnyékoláshoz először a neutronsugárzást le kell lassítani, majd a már lassú neutronokat el kell nyeletni. A sugárzás lassítása azon alapszik, hogy egy ütközéskor az átadott energiahányad annál nagyobb, minél inkább azonos a két ütköző test tömege. A neutron emiatt az elektronokkal ütköztetve érdemben nem is tudna energiát leadni, mivel a tömege annál 1840-szer nagyobb. Viszont az atommagok közül a kis magok tömege hasonló az neutron tömegéhez. A leghatékonyabb módja a neutronok lassításának, ha a magas hidrogéntartalmú anyagokat használnak, pl.: víz, paraffin. A lassítás hatékonysága azon alapszik, hogy a közönséges hidrogén atommagjának (egyetlen proton) tömege szinte teljesen azonos a neutronéval. A proton ráadásul viszonylag jó eséllyel el is nyeli a lelassított neutront, miközben deutériummá alakul.

A neutronsugárzásból származó dózisteljesítmény számolása meglehetősen bonyolult feladat, mert a neutronsugárzás energiájától függően más-más biológiai hatásokkal kell számolni. A neutronok esetében szükség van a neutronra vonatkozó sugárzási tényező ismeretére, ami függ a neutron energiájától. Viszonylag egyszerü a számítás, ha az átlagos $5 \mathrm{MeV}$ energiára jellemző neutron fluens - 
effektív dózis konverziós tényezőt tekintjük. Ez az érték [9] szerint $494 \mathrm{pSv} / \mathrm{cm}^{2}$. A neutronforrástól $30 \mathrm{~cm}$-re a neutronfluxus $2,651 / \mathrm{cm}^{2} \mathrm{~s}$, ami $1,31 \mathrm{nSv} / \mathrm{s}=4,72 \mu \mathrm{Sv} / \mathrm{h}$ dózisintenzitást jelent. Ez nem egy veszélyes érték, különösen, ha figyelembe vesszük, hogy a $20 \mathrm{~cm}$ vastag paraffin réteg ezt a dózisintenzitást még $\mathrm{kb}$. a tizedére, azaz $\mathrm{kb} 0,5 \mu \mathrm{Sv} / \mathrm{h}$ értékre csökkenti. (Megjegyezzük, hogy számos irodalom a fluens és fluxus mennyiségeket máshogy értelmezi, mi ebben a cikkben az érvényes szabványt követjük.)
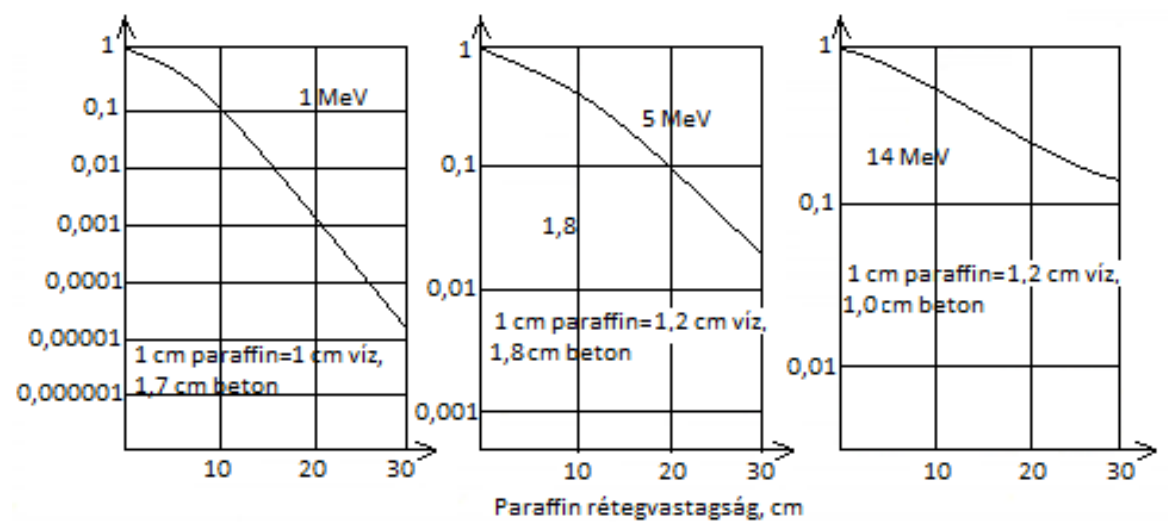

5. ábra. A paraffin neutronárnyékoló hatása a rétegvastagságának a függvényében különbözö neutron energiákon [4]. A függöleges tengelyen a dózisteljesitmény gyengitési rátája látható

\subsection{Gamma háttér}

A Ra-226 bomlási sorának gamma sugárzása is jelentős. A dózisállandó (dózis konverziós tényező) értéke az irodalom szerint $193 \mu \mathrm{Gy} \cdot \mathrm{m}^{2} \cdot \mathrm{h}^{-1} \cdot \mathrm{GBq}^{-1},[10]$ ami a mi forrásunk esetében, a forrástól $30 \mathrm{~cm}-$ re $238 \mu \mathrm{Gy} \cdot \mathrm{h}^{-1}$ dózisintenzitást eredményezne. Ez megengedhetetlenül magas érték lenne a berendezés hozzáférhető felszínén. Emiatt a sugárforrás ólomtégelybe van helyezve, amelynek a falvastagsága kb. $5 \mathrm{~cm}$. Ekkora ólomréteg a gamma sugárzást kb. 5\%-ra csökkenti, amely a hozzáférhetö felszínén 10 $\mu \mathrm{Gy} \cdot \mathrm{h}^{-1}$ alatti dózisintenzitásra vezet (tekintve, hogy a paraffinnak is van azért egy kicsi gamma árnyékoló képessége). A szétszedés után kiderült, hogy az ólomtégely a valóságban kissé aszimmetrikus, azaz a forrást tartalmazó furat nem az ólomhenger tengelyén van, hanem attól $1-2 \mathrm{~cm}-$ re. Ez - a fazék aszimmetrikus elhelyezése miatt - egy nagyon logikus kialakítás, mert így a közelebbi külső tartályfelszín felé valamivel nagyobb az árnyékolás. Azaz a fenti $10 \mu \mathrm{Gy} \cdot \mathrm{h}^{-1}$ dózisintenzitás mindenképpen felülbecslés.

Megjegyezzük, hogy másféle alfa-sugárzó radioaktív izotópos neutronforrások (Po-Be, $\mathrm{Pu}-\mathrm{Be}, \mathrm{Am}$ Be) gamma sugárzása sokkal kisebb, azoknál az ólomtégely sem feltétlenül szükséges.

\subsection{A neutronforrás felhasználása: rövid felezési idejü ezüst izotópok gyártása neutron aktivációval}

A neutronforrásunk kicsi hozama (másodpercenként kb. 30000 neutron) nagyban leegyszerüsíti a sugárvédelmét, ugyanakkor erősen korlátozza a felhasználási lehetőségeit is. Ez a neutronhozam elegendö lehet pl. neutron detektorok müködésének demonstrálására, tesztelésére és fejlesztésére a kisebb dózisok tartományában. Egészen biztosan nem elegendő tudományos vagy ipari pontosságú neutron aktivációra, de oktatási, demonstrációs célokra ezen a területen is kiváló lehet. 
A neutron aktiváció során a különböző anyagok stabil izotópjaiból eggyel nagyobb tömegszámú radioaktív izotóp keletkezik [11]. Ezek sugárzása kijuthat az anyag belsejéből, sugárzásmérő müszerekkel azonosítható, segítségükkel roncsolásmentes térfogati anyagvizsgálat lehetséges. A mi kis neutronhozamunk esetében csak nagy hatáskeresztmetszetü neutron elnyelődést követő gyors béta bomlások kimutatására van reális esély. Ezeket a feltételeket az ezüst izotópjai jól teljesítik.

$\mathrm{Az}$ ezüstnek két stabil izotópja van, kb. fele-fele arányban tartalmazza a természetes ezüst, mindkettő felaktiválható az alábbi $(\mathrm{n}, \gamma)$ reakciókkal:

$$
\begin{aligned}
& { }_{47}^{107} A g+n \rightarrow{ }_{47}^{108} A^{*}{ }^{*} \rightarrow{ }_{47}^{108} A g+\gamma \\
& { }_{47}^{109} A g+n \rightarrow{ }_{47}^{110} A g^{*} \rightarrow{ }_{47}^{110} A g+\gamma
\end{aligned}
$$

A reakcióknak a hatáskeresztmetszete termikus energiára lelassított neutronokra a legnagyobb $\left(\sigma_{107}=36\right.$ ill. $\sigma_{109}=87$ barn; 1 barn $\left.=10^{-24} \mathrm{~cm}^{2}\right)$. A keletkezett 108 -as és 110 -es tömegszámú ezüst izotópok (általában) $\beta^{-}$bomlással kadmiummá bomlanak 2,37 perces, ill. 24 másodperces felezési idővel.

$$
\begin{gathered}
{ }_{47}^{108} \mathrm{Ag} \rightarrow{ }_{47}^{108} \mathrm{Cd}+e^{-}\left(+v^{e}\right) \quad \mathrm{T}_{1 / 2}=2,37 \mathrm{~min} \\
{ }_{47}^{110} \mathrm{Ag} \rightarrow{ }_{47}^{110} \mathrm{Cd}+e^{-}\left(+v^{e}\right) \quad \mathrm{T}_{1 / 2}=24 s
\end{gathered}
$$

Tételezzük fel, hogy az egyik besugárzási csatornában az ezüst tárgy (pl. gyürü) $10 \mathrm{~cm}$ távolságra kerül a netronforrástól. Ott a neutron fluxus $\Phi=241 / \mathrm{s} \cdot \mathrm{cm}^{2}$. Az időegységenként keletkezett radioaktív atomok száma:

$$
d N_{\mathrm{rad}} / d t=N_{\text {stab }} \cdot \Phi \cdot \sigma
$$

Ha az ezüst mennyisége pl. $0,2 \mathrm{~mol}(\sim 22 \mathrm{~g})$ az $\mathrm{N}_{\text {stab }}=3 \cdot 10^{22} \mathrm{db}$ atomot jelent mindkét izotópból. Ekkor másodpercenként 52 illetve 125 atom(mag) keletkezik a két radioaktív izotópból. (Ez persze igen durva számolás, mert a neutronok közel a forrásukhoz még nem termikusak, másrészt visszafelé is szóródhatnak.) A keletkezett radioaktív atomok persze rögtön bomlani kezdenek a rájuk jellemző felezési idővel. Számuk növekedése nyilvánvalóan addig tarthat, amíg a radioaktív bomlások száma el nem éri a keletkezések számát, tehát az aktivitások határértéke a két izotópra $52 \mathrm{~Bq}$ és $125 \mathrm{~Bq}$. Ennek 99\%-át már 7 felezési idő alatt eléri, ez pedig 17 perc, ill. 3 perc alatt bekövetkezik. Ennél hosszabb ideig értelmetlen az ezüst darabot a neutronforrásnál tartani. (Sőt az egyéb radioaktív izotópok felszaporodása miatt egyenesen káros is.)

A továbbiakat az dönti el, hogy a felaktivált ezüst milyen gyorsan juttatható el a laboratóriumi méröhelyre. A mi körülményeink között ehhez minimum 2 percre van szükség. Ez alatt a ${ }^{110} \mathrm{Ag}$-nak a 97\%-a már elbomlik, a néhány Bq-nyi aktivitás pedig a mi eszközeinkkel már nem igazán mérhető. A ${ }^{108} \mathrm{Ag}$-nak az aktivitása azonban 2 perc alatt még a felére sem csökken, a kb. 30Bq aktivitás a mi eszközeinkkel is jól mérhető, az aktivitás időfüggése jól követhető.

Összefoglalva: a Ra-Be neutronforrással igen jól megvalósítható a felaktivált ezüst ${ }^{108} \mathrm{Ag}$-izotópja béta bomlása időfüggésének mérése. A méréssel a minta ezüst tartalma nem határozható meg pontosan, de a hasonló formájúra készített minták közül az ezüst (ezüst tartalmú) könnyedén kiválasztható. 


\section{A neutronforrás temetésre történő előkészítése és eltemetése}

A Ra - 226 - Be zárt sugárforrást tartalmazó eszközből a forrás kiszerelésénél, azaz a munka megkezdésénél az első lépés volt a munkaeszközök [12] előkészítése, amelyek a következők voltak:

- müszerek: Victoreen 451 P - gamma dózisteljesítmény mérö, Thermo FG 40 GL 10 - gamma dózisteljesítmény mérő, személyi dózismérő - az egyéni sugárterhelés ellenőrzésére, Red Eye AB 100 - felületi szennyezettség mérö, Canary - radon mérö,

- különbözö szerszámok: csillagcsavarhúzó, fogó, stb. - az ólomtok felnyitásához, 2 db hő légfúvó paraffin olvasztásához, merőkanál - az olvadt paraffin eltávolításához, tároló edény - az olvadt paraffin tárolására,

- egyéni védőeszközök: gumikesztyü, eldobható köpeny, lábzsák, szájmaszk.

Az előkészületek fontos eleme volt a terület biztosítása. Szerencsés helyzet volt, hogy az Izotóptároló a Fizikai Intézet zárható folyosóján helyezkedik el, így a terület lezárása lehetséges volt. Vizsgaidőszakban, pénteken ez alig zavarta az Intézet munkáját.

\subsection{A paraffin eltávolítása}

A forrást körülvevő paraffin olvadáshője $47^{\circ} \mathrm{C}$ és $67^{\circ} \mathrm{C}$ között van, így annak megolvasztásához nem szükséges túl nagy hőmérséklet. A paraffin megolvasztásának lehetőségei között szóba jött, az egész eszköz alulról (melegíthető homokfürdő) történő megolvasztása (6. ábra). Ez a fütési mód azonban nem bizonyult elégségesnek, a munka során a hatékonyabb fütési módok kiegészítését jelentette. Ez a hatékonyabb fütési mód a paraffin felülről hő légfúvókkal történő melegítése volt (7. ábra). A hő légfúvók a paraffint egy pontra koncentrálva, melegítve olvasztja meg azt. A megolvadt paraffin a körülötte lévő paraffin megolvadását elősegíti. Miután megfelelő mennyiségü paraffin megolvadt elkezdtük annak eltávolítását. Az eltávolításnál figyelni kellett arra, hogy a már megolvadt paraffin nehogy égési sérülést okozzon.

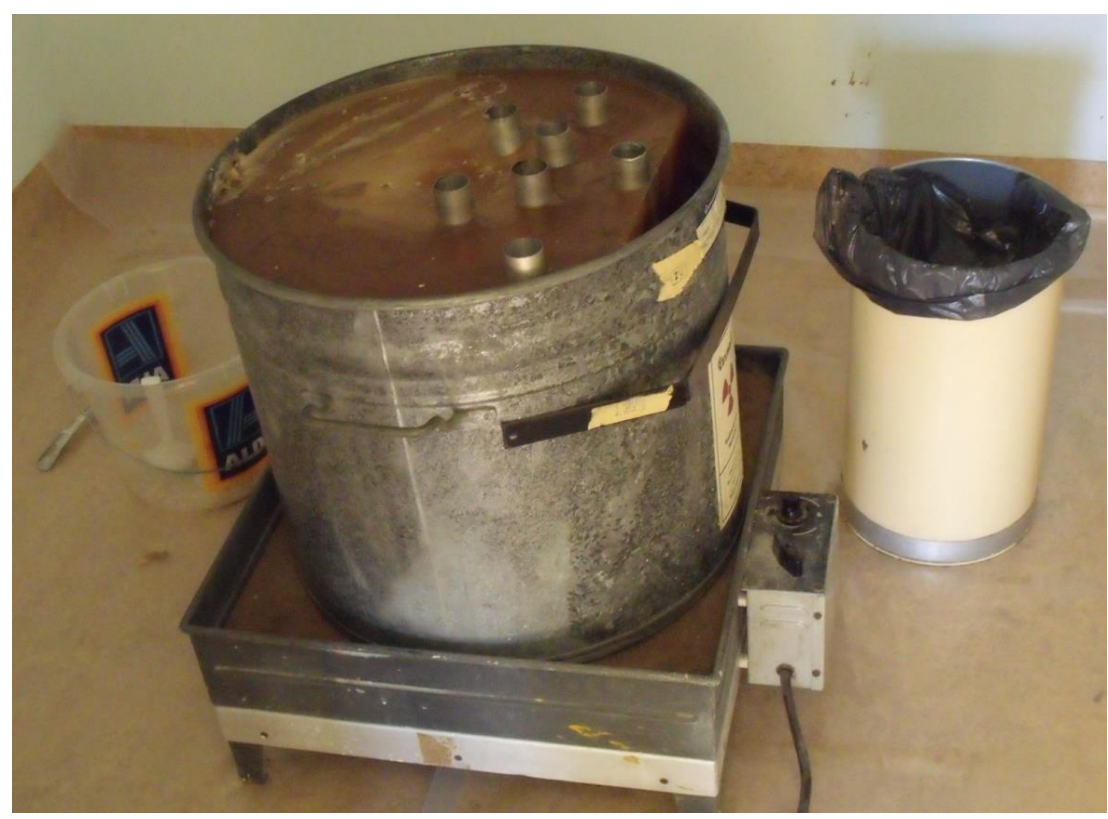

6. ábra. A Ra-226-Be zárt sugárforrás kiindulási állapota 


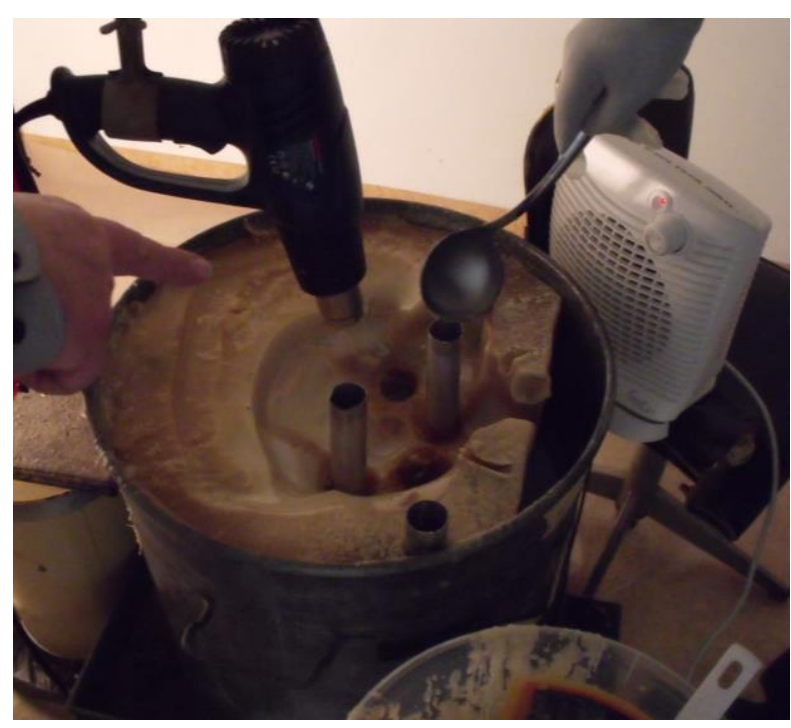

7. ábra. A paraffin olvasztásának folyamata

Az eltávolított paraffin darabokat felületi szennyezettség mérővel folyamatosan megmértük, annak érdekében, hogy az esetleges forráseresztést a lehető leghamarabb észrevegyük. Továbbá azért, hogy tisztában legyünk azzal, hogy az eltávolított paraffin inaktív, azaz a radioaktív szennyezettségtől mentes. A felületi szennyezettség mérés mellett a leghatékonyabb mérési módszer arra, hogy észrevegyük a tokozás esetleges sérülését, a radon mérés. A radon koncentráció $28 \mathrm{~Bq} / \mathrm{m}^{3}$ volt a levegöben, ami a kezdeti értékhez képest nem növekedett.

A paraffin olvadása közben a besugárzási csatornákat egyesével, folyamatosan el lehetett távolítani az eszközből. A [13] cikk alapján azt feltételeztük, hogy a forrás középen, az edény alján helyezkedik el. A paraffin eltávolítása közben azonban a sugárforrást tartalmazó ólomtok a vártnál hamarabb megjelent (8. ábra), mivel az nem a fazék alján, hanem az alsó egyharmadának a tetején volt elhelyezve.

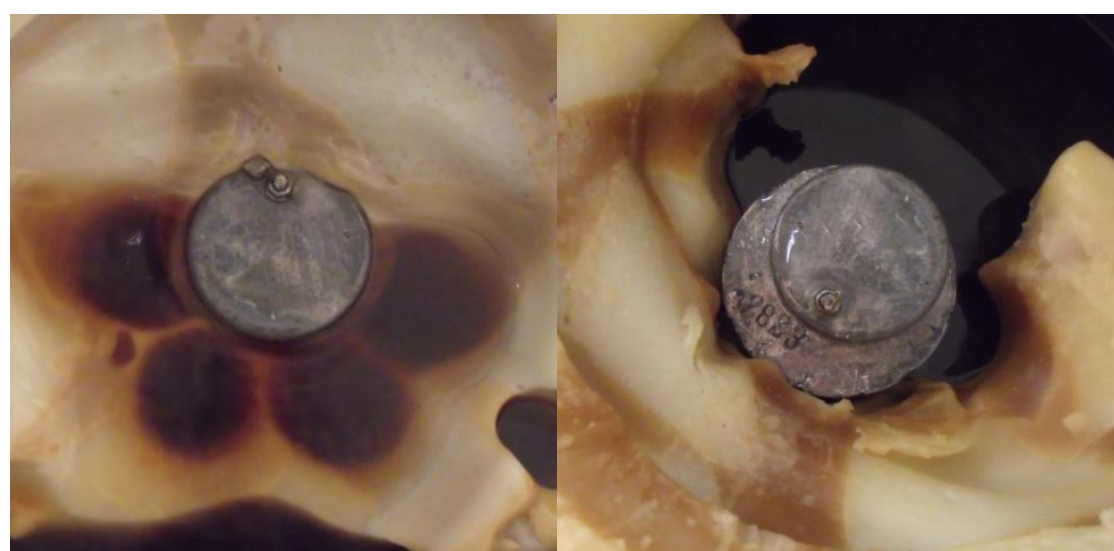

8. ábra. Megjelenik az ólomtokozás teteje (balra), majd az egész ólomtok is (jobbra)

Az ólomtok megjelenése után a melegítést még óvatosabban kellett végezni, nehogy a melegítéssel megsértsük a benne található sugárforrást. Mivel semmilyen információnk nem volt az ólomtégely 
méretéről illetve annak gyári kialakításáról, nem tudtuk azt sem hogy az ólomtégelyben pontosan hol található a forrás. A radon mérése folyamatos volt a melegítés során, továbbá a gamma dózisteljesítmény változását is nyomon követtük.

\subsection{A sugárforrás kiszerelése}

A sugárforrás az eszköz aljától körülbelül $15 \mathrm{~cm}$ magasságban volt elhelyezve, az ólomtégely stabil lábakon állt, amelyet úgy alakítottak, ki hogy az ólomtégely a lehető legstabilabban maradjon. A lábakat az ólomtégelyhez hegesztéssel rögzítették. A neutron aktivációs analízis végzéséhez fontos tudni a forrás pontos helyzetét. Ezen okból sem volt megengedhetö, hogy a forrás helyzete elmozduljon, miközben paraffinnal töltik fel az eszközt. Kiszerelt ólomtokot és a benne lévő Ra-226Be zárt sugárforrást a 9. ábra mutatja:

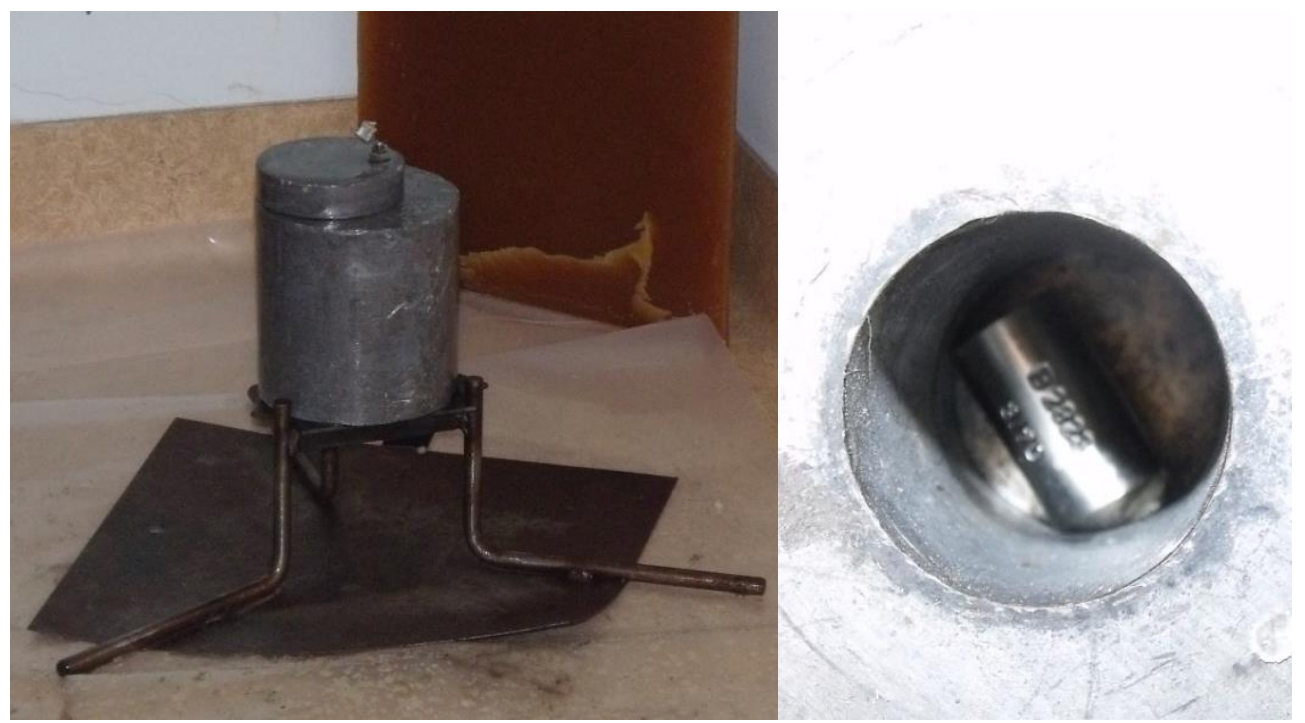

9. ábra. A paraffinból kiszedett ólomtok (balra) és a belöle kiszerelt sugárforrás (jobbra)

A zárt sugárforrás ólomtokban volt elhelyezve, a tokon található ólomdugó le volt plombázva, ami azt jelenti, hogy a gyártás után a forráshoz senki nem nyúlt hozzá. Ez fontos információ volt számunkra, mert így tudtuk, hogy semmilyen váratlan dologgal nem kell szembesülni (ilyen lehetett volna például a forrás újra tokozása). Az ólomtégelyen leolvasható volt egy szám, a 2823, ami az ólomtégely gyári minősítésének számát adja meg. A forrás kiszerelésénél figyelembe kellett venni, hogy az ólomtok aszimmetrikus kialakítású fészekben volt elhelyezve.

\subsection{A munkafolyamat befejezése}

Miután a radioaktív sugárforrásról eltávolítottuk a paraffint és az ólomtégelyt is sikeresen felnyitottuk, a sugárforrás láthatóvá vált. Az elökészítő munkánk célja az volt, hogy a sugárforrást elökészítsük a radioaktív hulladéktemetőbe történő elszállításhoz, azaz a lehető legkisebb méretig eltávolítani róla a sugárvédelmi anyagokat (paraffin, ólom). Ezt a célt teljesítettük akkor, amikor az izotópot kiszedtük az ólomtartályból. Ez természetesen megfelelő segédeszközökkel történt, kézzel nem érintettük az izotópot és a testünkkel is a lehető legnagyobb távolságot tartottunk tőle. Ezt követően a forrást 
tartalmazó ólomtégelyről az ionizáló sugárázást jelző piktogramot el kellett távolítani. Azért fontos a sugárveszélyes jel eltávolítása, hogy később ne tévessze meg azokat a dolgozókat, akik az ólomtégelyt megtalálják.

Az izotóp csak másodpercekre volt szabadon, rögtön a számára kialakított ideiglenes védő helyre helyeztük. Ugyanis az izotópunk radioaktív hulladéktemetőbe szállításának időpontját előre fixálnunk kellett, miközben az előkészítő munka (az izotóp kiszerelésének) időtartamát lehetetlen volt előre megbecsülni. Korábban már említettük, hogy a kiszerelő munkát pénteken végeztük, mivel a munkaterületet akkor lehetett lezárni. Így az elszállításra csak a következő hét elejére programozhattuk. (A pénteki előkészítésnek az is előnye, hogy bármilyen csúszás esetén a munka szombaton is folytatható lett volna. Szerencsére erre nem került sor.)

A sugárforrás átmeneti tárolására is a Fizikai Intézet Izotóptároló helyiségében került sor. A forrást erre a néhány napra is az eredeti védelemmel kb. ekvivalens sugárvédelemmel láttuk el. Az izotópot visszahelyeztük az ólomtégelybe, majd az olvadt paraffint, (amit korábban különbözö edényekbe helyeztük) az ólomtégely köré tudtuk helyezni, ezzel biztosítva a forrás neutronsugárzás elleni védelmét.

A munkaterület elhagyása előtt az Izotóptárolót és a tároló bejárata előtti folyosót felületi szennyezettség mérővel végig mértük, erre azért volt szükség, hogy az esetleges izotópszennyeződést teljesen ki lehessen zárni. A felületi szennyezettség mérő most is a hátérrel megegyezö beütésszámot mutatta, tehát az izotóp tokozása sértetlen maradt. A terület körbemérése után a használt személyi védőeszközöket, a gumikesztyüt, az egyszer használatos köpenyt, a lábzsákot is megmértük. A szennyezettség mérés után, a tároló illetve a szomszédos helyiség gamma dózisát mértük meg, a gamma dózisteljesítmény $100-150 \mathrm{nSv} / \mathrm{h}$ között volt, ami a természetes háttérnek felel meg. Tehát az Izotóptároló környékén tartózkodó dolgozókra (lakosságra) nem jelentett többlet sugárterhelést az Izotóptárolóban elhelyezett sugárforrás.

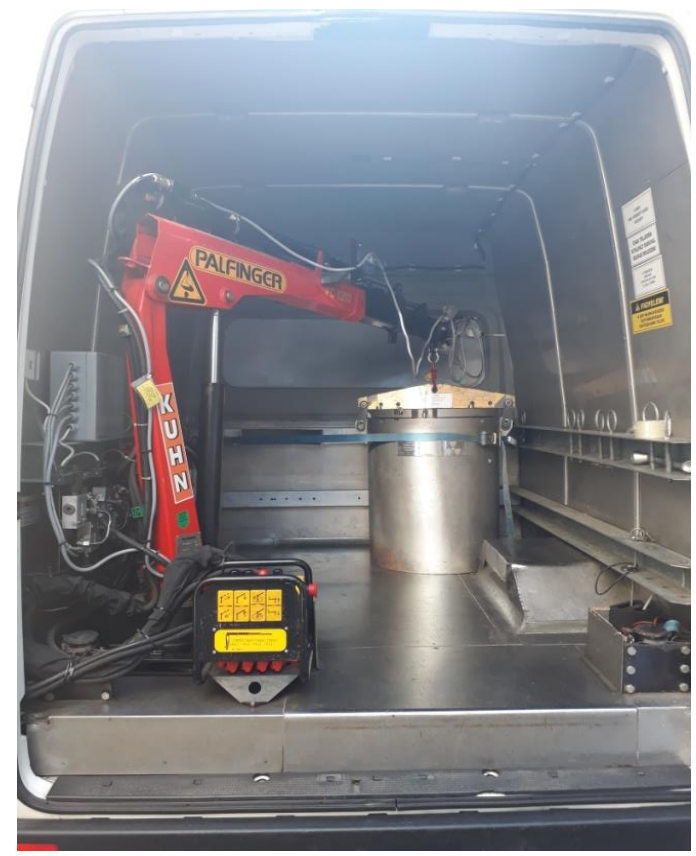

10. ábra. A neutronforrás már az RHK Kft. az izotópszállitó autója rakterében lévő ólomtartályban van 
E mérésekkel párhuzamosan sort kerítettünk a kiszerelt izotóp újabb (és egyben utolsó) zártságvizsgálatára. A zártságvizsgálatra elvégzésére azért is szükség volt, mert az RHK Kft. (Radioaktív Hulladékokat Kezelő Közhasznú Nonprofit Kft.) [14] részére temetésre csak olyan sugárforrás adható át, amely rendelkezik egy évnél nem régebbi zártságvizsgálattal. A zártságvizsgálatról szakvéleményt kellett kiállítani. (Amennyiben a forrás tokozása megsérült volna, a forrás maga nyitottá vált volna, így teljesen más eljárási módszerrel kellett volna a RHK Kft.-nek átadni.)

A RHK Kft. az izotóp elszállítását az előre megbeszélt időpontban elvégezte (10. ábra).

\section{Következtetések}

A Ra-Be neutronforrás temetésre történő előkészítése hazai viszonylatban egyedülálló, szakmailag komoly feladatot jelentett. A munka során - alkalmazkodva a sugárvédelem alapelveihez - betartottuk az indokoltság - optimálás - dóziskorlátozás hármas követelményét. Az elöző fejezetekben leírtak szerint a munka nyilvánvalóan indokolt volt (sőt a vonatkozó elöírások szerint kötelező). Az ésszerüen elérhető legalacsonyabb dózisszintet (optimálás) a munkafolyamatok pontos megtervezésével, a forrás közvetlen környezetében töltött idöt a lehető legrövidebbre redukálásával és a távolságvédelemmel (az effektív munkavégzés alatt is igyekeztünk a testünket minél távolabb tartani a forrástól) értük el. A munka közben elszenvedett effektív dózist ilyen inhomogén és komplex terekben lehetetlen pontosan megadni. Abban azonban a méréseink alapján biztosak vagyunk, hogy ez nem érte el a sugárártalmas munkahelyen dolgozókra megengedett éves korlát 1\%-át, ami $0,2 \mathrm{mSv}$. Ez összhangban van az „A” kategóriájú dolgozó személyi dózismérési adatával is.

A 44 éve gyártott neutronforrás minden elemét igen jó állapotban találtuk, a sugárforráson nem voltak sérülések, korrózió nyomok. A sugárforrás tökéletesen zárt volt minden alfa- és béta sugárzó izotópra. A sugárforrás eltemetését az állapota még nem indokolta, az még hosszú évtizedeken át szolgálhatta volna az oktatást.

A kérdés másik oldala az, hogy igényelte-e volna-e még ezt a neutronforrást az oktatásunk (esetleg a kutatásunk). A jövő nyilvánvalóan generálhat még új igényeket, de ha csak a közelmúltat tekintjük, akkor a válasz a „nem igazán”. Ugyanis a forrás a kis neutronhozama miatt csak demonstrációs célokat tud szolgálni, semmiképpen sem alkalmas kvantitatív neutron aktivációs (esetleg pénzt is hozó) vizsgálatokra. A cikkben leírt alkalmazás (rövid felezési idejű ezüst izotópok gyártása a felezési idejük hallgatói laborban történő megmérése céljából) egy jó alkalmazás lehetett volna, ilyen jellegü mérésekre azonban a különböző szakok vezetői a tananyag fejlesztések során nem tartottak igényt. Ilyen jellegü mérésekre egyébként a neutronforrás hiányában is marad lehetőség a szoba levegőjéből kiszürt radon bomlástermékek $\left({ }^{218} \mathrm{Po},{ }^{214} \mathrm{~Pb},{ }^{214} \mathrm{Bi},{ }^{214} \mathrm{Po}\right)$ mérésével.

\section{Irodalom}

[1] 487/2015. (XII. 30.) Korm. rendelet az ionizáló sugárzás elleni védelemről és a kapcsolódó engedélyezési, jelentési és ellenőrzési rendszerről

[2] www.inis.hu

[3] Nagy, L., Szakolyi, L.: Neutronaktiválásos vizsgálatok, Budapest: Müszaki könyvkiadó, 1966.

[4] Lengyel, T., Jász, Á.: Izotóplaboratórium zsebkönyv, Budapest: Müszaki Könyvkiadó, 1966.

[5] Paripás, B.: Lakószobai radon- és radon bomlástermék expozíciók meghatározása szilárdtest nyomdetektorral, Egyetemi doktori értekezés, Témavezető: Somogyi Gy., KLTE, Debrecen, 1985 . 
[6] Häussinger, P. et al.: Noble Gases. In: Ullmann's Encyclopedia of Industrial Chemistry. WileyVCH, Weinheim 2006 https://doi.org/10.1002/14356007.a17_485

[7] Bak, M.A., Romanov, J.F.: A neutron, Budapest: Müszaki Könyvkiadó, 1963.

[8] https://www.nrc.gov/docs/ML1122/ML11229A704.pdf

[9] MSZ 62-3:2017. Az ionizáló sugárzás elleni védelem 3. rész: A neutron sugárzás elleni védelem, 2017 november

[10] MSZ 62-2:2017. A foton- és elektronsugárzás elleni védelem.

[11] Bódizs, D.: Radioaktív sugárzások méréstechnikái, Budapest: Typotex, 2006.

[12] Kiss, D., Quitner, P.: Neutronok, Budapest: Akadémia Kiadó, 1971. M. A.

[13] Didi, A., Dadouch, A., Tajmouati, J.: Design of Irradiation Channels in Radium-Beryllium 226Ra-Be Neutron Irradiation Facility Usmba-Fsdm-Fez Morocco, Elixir Nuclear \& Radiation Phys. 83 (2015) 32963.

[14] https://rhk.hu/storage/galleries/13/Hullad\%

C3\%A9k\%C3\%A1tv\%C3\%A9teli\%20k\%C3\%B6vetelm\%C3\%A9nyek.pdf 